\title{
ANALISIS FAKTOR-FAKTOR YANG MEMPENGARUHI KINERJA SISTEM INFORMASI AKUNTANSI PADA PT. SINAR GALESONG MANDIRI
}

\author{
Sitti Zulaeha \\ sittizulaeha@unismuh.ac.id \\ Ayu Puspita Sari \\ ayupspitas97@gmail.com \\ Fakultas Ekonomi dan Bisnis \\ Universitas Muhammadiyah Makassar
}

\begin{abstract}
Analysis of Factors Affecting Accounting Information System Performance at PT. Sinar Galesong Mandiri, Thesis Accounting Study Program Faculty of Economics and Business Muhammadiyah University Makassar. Supervised by Supervisor I Ansyarif Khalid and Supervisor II Sitti Zulaeha. This study aims to obtain empirical evidence using primary data regarding Factors Affecting Accounting Information System Performance at PT. Sinar Galesong Mandiri. This type of research used in research is correlational with a quantitative approach. The population and sample in this study are based on certain criteria or puposive sampling techniques of 43 respondents. The results showed that the user involvement variable had no significant effect on the performance of accounting information systems. While a variety of training and education program variables, personal technical abilities, facilities and top management support significantly influence the performance of accounting information systems.
\end{abstract}

Key words : Accounting Information System Performance, Training and Education Programs, User Engagement,

\section{Abstrak}

Sinar Galesong Mandiri, Skripsi Program Studi Akuntansi Fakultas Ekonomi dan Bisnis Universitas Muhammadiyah Makassar. Dibimbing oleh Pembimbing I Ansyarif Khalid dan Pembimbing II Sitti Zulaeha. Penelitian ini bertujuan untuk memperoleh bukti empiris dengan menggunakan data primer mengenai Faktor-Faktor yang Mempengaruhi Kinerja Sistem Informasi Akuntansi pada PT. Sinar Galesong Mandiri. Jenis penelitian yang digunakan dalam penelitian adalah korelasional dengan pendekatan kuantitatif. Populasi dan sampel pada penelitian ini berdasarkan kriteria tertentu atau puposive teknik sampling sebanyak 43 responden. Hasil penelitian menunjukkan bahwa variabel keterlibatan pemakai berpengaruh tidak signifikan terhadap kinerja sistem informasi akuntansi. Sedangkang variabel program pelatihan dan pendidikan, kemampuan teknik personal, fasilitas dan dukungan manajemen puncak berpengaruh signifikan terhadap kinerja sistem informasi akuntansi.

Kata Kunci: Kinerja Sistem Informasi Akuntansi, Program Pelatihan dan Pendidikan, Keterlibatan Pemakai. 


\section{PENDAHULUAN}

Istilah industri 4.0 lahir dari ide revolusi keempat. Beberapa pendapat mengatakan industri 4.0 mengenai perbaikan kecepatan fleksibilitas produksi, peningkatan pelayanan kepada pelanggan dan peningkatan pendapatan, sehingga berdampak pada perekonomian suatu negara. Sehingga perusahaan dituntut untuk mampu dan bertahan dalam dunia bisnis yang terus berkembang. Dalam melaksanakan kegiatannya, perusahaan pada umumnya sangat memerlukan sistem akuntansi yang efisien dan efektif, khususnya dengan kebutuhan manajemen maupun berbagai pihak di luar perusahaan yang memerlukannya. Informasi memang menjadi unsur penentu dalam pengambilan keputusan, baik oleh manajemen perusahaan itu sendiri maupun pihak-pihak yang berkepentingan dengan perusahaan.

Penerapan suatu sistem dalam perusahaan dihadapkan kepada dua hal yaitu apakah perusahaan mendapatkan keberhasilan dalam penerapan sistem atau sebaliknya. Secara tipikal, suatu sistem dikatakan berhasil apabila telah memenuhi tiga kondisi yakni: penggunaan dari sistem tersebut meningkat, persepsi pemakai atas kualitas sistem lebih baik dari sebelummya, atau kepuasan pemakai informasi meningkat (Susilatri, dkk : 2010). Secara umum dapat dikatakan bahwa informasi yang objektif akan mendukung efisiensi. Demikian pula informasi akuntansi, apabila disajikan dengan bertolak pada sistem yang andal tentu akan menghasilkan informasi yang objektif.

Oleh karena itu, penugasan penyusunan sistem informasi akuntansi hendaknya selalu dilaksanakan dengan satu tujuan, yaitu agar informasi yang dihasilkannya adalah informasi yang objektif sehingga mereka yang menggunakannya akan dapat mengambil keputusan dengan tepat.

Keberadaan sistem informasi akuntansi dapat membantu pekerja memahami batasan tanggung jawab dan tugas yang diberikan kepadanya. Bagi pekerja, semakin jelas batasan tanggung jawab dan tugas yang diberikan kepadanya akan merangsang individuindividu untuk melakukan pekerjaan sebaik mungkin dan melakukan inovasi agar mendapatkan penilaian kinerja yang baik dari atasan. Selain itu, keberadaan sistem informasi akuntansi juga berperan sebagai pengamanan harta kekayaan perusahaan. Dengan adanya unsur-unsur pengendalian atau pengecekan dalam sistem akuntansi, berbagai kecurangan, penyimpangan, dan kesalahan, dapat dihindarkan atau dilacak sehinga dapat diperbaiki.

Suharni (2016) dengan judul "Pengaruh Keterlibatan Pemakai Dan Kemampuan Pemakai Terhadap Kinerja Sistem Informasi Akuntansi Pada Sekretariat Daerah Dan BKD Kabupaten Ngawi". Hasil penelitian yang dilakukan bahwa variabel terikat digunakan uji $\mathrm{F}$, menunjukkan bahwa nilai $\mathrm{F}$ hitung 18,319. Nilai ini lebih besar dari t tabel $(18,319>3,26)$ dengan tingkat signifikan F hitung sebesar 0,000. Hasil ini memperlihatkan bahwa variabel keterlibatan pemakai dan juga kemampuan pemakai memiliki pengaruh yang signifikan terhadap kinerja sistem informasi akuntansi.

Dari uraian diatas maka tidak semua keterlibatan pemakai membawa keberhasilan dalam pengembangan sistem informasi, ada beberapa alasan yang menyebabkan terjadinya kegagalan 
yaitu salah satunya tidak tepatnya pengetahuan yang dimiliki pemakai sehingga tidak bersedia membuat keputusan atau memberikan pandangannya, karena pemakai kurang memahami dampak dari keputusan yang diambilnya. Berdasarkan uraian diatas maka penulis tertarik untuk membahas suatu penelitian yang berjudul "Analisis Faktor-Faktor Yang Mempengaruhi Kinerja Sistem Informasi Akuntansi Pada PT. Sinar Galesong Mandiri".

\section{TINJAUAN PUSTAKA}

\section{a. Pengertian Sistem Informasi Akuntansi}

Statement of Financial Accounting Concept No.2, Financial Accounting Standards Board mendefinisikan akuntansi sebagai sistem informasi. Sistem informasi akuntansi adalah sebuah sistem yang memproses data dan transaksi guna menghasilkan informasi yang bermanfaat untuk merencakan, mengendalikan, dan mengoperasikan bisnis.

Mardi (2016:4) mengemukakan bahwa sistem informasi akuntansi sebagai suatu kegiatan yang terintegrasi yang menghasilkan laporan di bentuk data transaksi bisnis yang diolah dan disajikan sehingga menjadi sebuah laporam keuangan yang memiliki arti bagi pihak yang membutuhkan.

\section{b. Kinerja Sistem Informasi Akuntansi}

Menurut La Ane dan Anggraini (2012) menyatakan bahwa kinerja sistem informasi akuntansi adalah tingkat kemampuan sistem sesuai dengan fungsinya dalam menghasilkan informasi yang dibutuhkan untuk mencapai tujuan tertentu yang dapat terlihat melalui kepuasan yang dibutuhkan pemakasi sistem informasi akuntansi dan pemakai sistem informasi akuntansi itu sendiri.
Dalam kinerjanya, sistem informasi akuntansi mengumpulkan data yang kemudian menguraikan aktifitas perusahaan, merubah data menjadi informasi, dan terakhir membuat informasi tersebut dapat digunakan oleh pemakai dari dalam dan luar perusahaan.

\section{c. Faktor-Faktor Yang Mempengaruhi Kinerja Sistem Informasi Akuntansi}

1. Program Pelatihan dan Pendidikan

Menurut Salmah (2012) Pelatihan adalah setiap usaha untuk memperbaiki performasi pekerjaan pada suatu pekerjaan. Rivaningrum (2015) mengemukakan bahwa pelatihan akan menghasilkan peningkatan sistem informasi akuntansi dalam pengambilan keputusan. Pelatihan karyawan ditujukan kepada karyawan yang akan mengoperasikan sistem akuntansi. Karyawan yang mengoperasikan sistem terdiri dari karyawan yang bertugas untuk menyiapkan masukan, mengolah data, dan mengoprasikan dan menjaga komponen fisik dan logis sistem akuntansi.

2. Keterlibatan Pemakai Sistem Rivaningrum mengemukakan bahwa keterlibatan pemakai dalam pengembangan sistem informasi akuntansi diartikan bahwa sebagai bentuk keterlibatan mental dan emosi pegawai. Saebani dan Anita (2016) mengemukakan bahwa keterlibatan pemakai dalam proses pengembangan sistem harus dibatasi dalam sistem informasi, keterlibatan pemakai disesuaikan dengan bagian masingmasing dan sistem informasi yang digunakan karyawan.

\section{Kemampuan Teknik Personal}

Nurhelmiah (2014) berpendapat bahwa Pemakai yang memiliki pengetahuan dan kemampuan yang 
memadai akan mendorong kinerja sistem infromasi akuntansi lebih tinggi. Pemakai sistem informasi akuntansi yang memiliki kemampuan teknik baik yang diperolehnya dari pendidikan atau dari pengalaman menggunakan sistem akan meningkatkan kepuasan dalam menggunakan dalam menggunakan sistem informasi akuntansi.

\section{Fasilitas}

Fasilitas diartikan sebagai sarana untuk melancarkan pelaksanaan fungsi atau usaha tertentu. Fasilitas juga diartikan sebagai sumberdaya fisik yang ditawarkan kepada pemakai pada perusahaan. Fasilitas pada sistem infromasi akuntansi berupa perangkat, kelengkapan, desain interior dan eksterior yang dirancang dengan sebaik mungkin untuk memudahkan pemakai sistem sehingga tercipta kinerja sistem informasi akuntansi yang baik.

5. Dukungan Manajemen Puncak

$$
\text { Menurut Nurhelmiah }
$$
mengemukakan bahwa dukungan manajemen puncak merupakan bentuk dukungan manajer terhadap pemakai sistem informasi . Dukungan manajemen puncak menggambarkan hak, tugas, kewajiban, dan perilaku yang sesuai dengan orang yang memegang posisi tertentu dalam konten sosial tertentu, dimana peran manajemen puncak sebagai pengaruh keberhasilan implementasi sistem baru dan pengembangan daya motif bawahan.

\section{d. Kerangka Konsep}

Secara sederhana, kerangka pemikiran dalam penelitian ini ditunjukkan dengan bagan sebagai sebrikut:

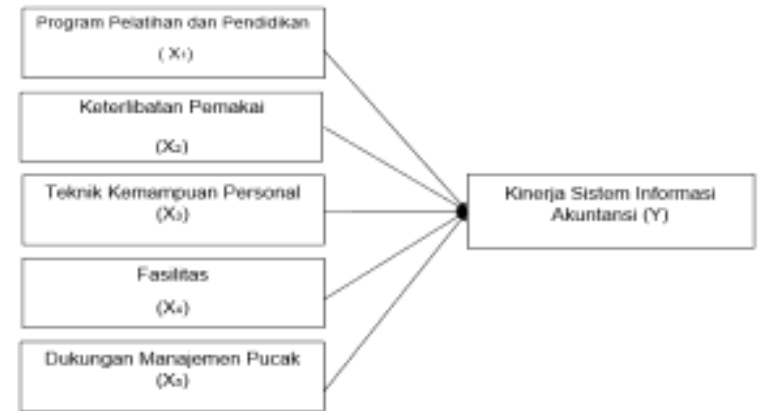

Sumber: Penulis, 2019

\section{METODE PENELITIAN}

\section{a. Uji kualitas data}

1. Uji Validitas

Suatu instrumen dikatakan valid apabila mampu mengukur sesuatu yang hendak diukur dan dapat mengungkapkan variabel yang hendak diteliti secara cepat. Validitas diuji dengan menggunakan besarnya korelasi antarvariabel.

2. Uji Reliabilitas

Uji reliabilitas menggunakan koefisien alpha $(\alpha)$. Jika hasil uji nilai $\alpha$ diatas 0,6 dan dilaksanakan pengukuran berulang dan tetap menghasilkan $\alpha$ diatas 0,6 maka data tersebut dinyatakan reliabel (dapat dipercaya).

\section{b. Uji Asumsi Klasik}

1. Uji Normalitas Data

Menurut Ghozali (2009:160-161) pengujian normalitas data berfungsi untuk menentukan distribusi data. Pengujian dilakukan dengan normal probability plot. Dikatakan variabel normal jika titik-titk data searah mengikuti garis diagonal.

2. Uji Heteroskedastisitas

Pengujian heteroskedastisitas dilakukan dengan menggunakan scatter plot nilai prediksi (sumbu X) dengan nilai residualnya (sumbu Y). Jika titik yang dihasilkan membentuk suatu pola tertentu, maka terjadi heterokedasitas. Jika tidak ada pola yang teratur atau titik- 
titik menyebar diatas dan dibawah angka 0 pada sumbu \&, maka tidak terjadi heterokedasitisitas (Ghozali,2009:125126).

\section{Uji Autokorelasi}

Terjadi korelasi, maka dinamakan ada problem autokorelasi. Menurut Setyadharma (2010) model regresi yang baik adalah regresi yang bebas dari autokorelasi. Dasar pengamatan pada penelitian ini menggunakan uji DurbinWatson.

\section{Uji Multikolinearitas}

Menurut Nisfiannoor (2009:92) uji multikolinearitas dilakukan untuk mengetahui apakah ada korelasi antarvariabel independen. Pengujian dilakuka dengan menggunakan variance inflation factors (VIF). Dikatakan multikolinearitas jika nilai VIF $<10$.

\section{c. Analisis Regresi Berganda}

Model regersi yang digunakan dalam penelitian ini adalah regresi berganda dengan menggunakan rumus sebagai berikut.

$$
\gamma=\alpha+\beta x_{1}+\beta x_{2}+\beta x_{3}+\beta x_{4}+\beta x_{5}+\varepsilon
$$

Keterangan:

$\mathrm{Y}=$ variabel terikat (kinerja pemakai sistem informasi akuntansi)

$\alpha=$ konstanta

$\beta=$ koefisien regresi

$x_{1}=$ program pelatihan dan pendidikan

$x_{2}=$ keterlibatan pemakai

$x_{3}=$ kemampuan teknik personal

$x_{4}=$ failitas

$x_{5}=$ dukungan manajemen puncak

$\epsilon=$ kesalahan residual

Analisis data secara keseluruhan akan menggunakan software SPSS 20 for windows. Hipotesis akan diuji dengan menggunakan uji F, uji t dan Detetrminasi.
Uji F dilakukan untuk menguji pengaruh variabel bebas secara bersama-sama. Jika $\mathrm{F}_{\text {hitung }}>\mathrm{F}_{\text {tabel }}$ maka $\mathrm{H}_{0}$ ditolak berarti $\mathrm{H}_{1}$ diterima. Uji t digunakan untuk menguji pengaruh variabel bebas secara persial. Jika $t_{\text {hitung }}>t_{\text {tabel }}$ maka $\mathrm{H}_{0}$ ditolak berarti $\mathrm{H}_{1}$ diterima (Nisfiannoor, 2009:174). Uji determinasi juga dilakukan untuk mengetahui persentase pengaruh variabel bebas secara keseluruhan terhadap variabel terikat berdasar nilai $R$ Squarenya pada tabel summary.

\section{HASIL DAN PEMBAHASAN}

\section{a. Uji Kualitas Data}

1. Uji Validitas

Penelitian ini menggunakan item pernyataan dalam kuesioner dengan jumlah responden 43. Sesuai dengan rumus yang digunakan $(\mathrm{df}=\mathrm{n}-2)$ maka akan menjadi $\mathrm{df}=43-2$ yaitu $41(\mathrm{df}=41)$. Berdasarkan kriteria dengan ketentuan df atau degree of freedom yang didapat $(\mathrm{df}=29$, dengan sig $5 \%$ atau 0,05$)$ maka nilai r-Tabel sebesar 0,3008. Merujuk pada hasil uji validitas dihasilkan bahwa semua instrumen dimulai dari P1,P2,P3 hingga P13 pada variabel $X$ semuanya menghasilkan nilai rHitung $>$ rTabel. Selain itu pada variabel Kinerja Sistem Informasi Akuntansi (Y) yang terdiri dari Y1,Y2,Y3 dan Y4 semuanya mengahsilkan nilai $r$ Hitung $>$ r-Tabel. Sehingga dapat disimpulkan bahwa semua instrumen pada penelitian ini dikatakan valid.

\section{Uji Reliabilitas}

Hasil pengujian ini membuktikan bahwa semua item pernyataan di kinerja sistem informasi akuntansi dan FaktorFaktor Pendukung Utama membuktikan data penelitian ini reliable karena nilai Cronbach's Alpha diatas 0,6. 
3. Uji Asumsi Klasik

a. Uji Normalitas Data

Gambar 4.1

Normal Probability Plot

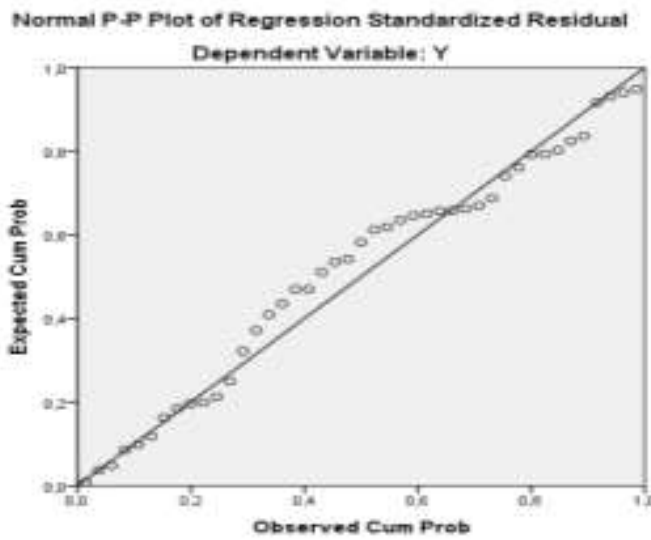

Berdasarkan hasil pengujian diagram P-Plot bahwa koordinat data pada sumbu absis observerd cum prob dan sumbu ordinat expected cum prob mengumupul pada garis diagonal. Hal ini berarti bahwa data penelitian ini berdistribusi normal.

b. Uji Heteroskedastisitas

Gambar 4.2

Scatter Plot

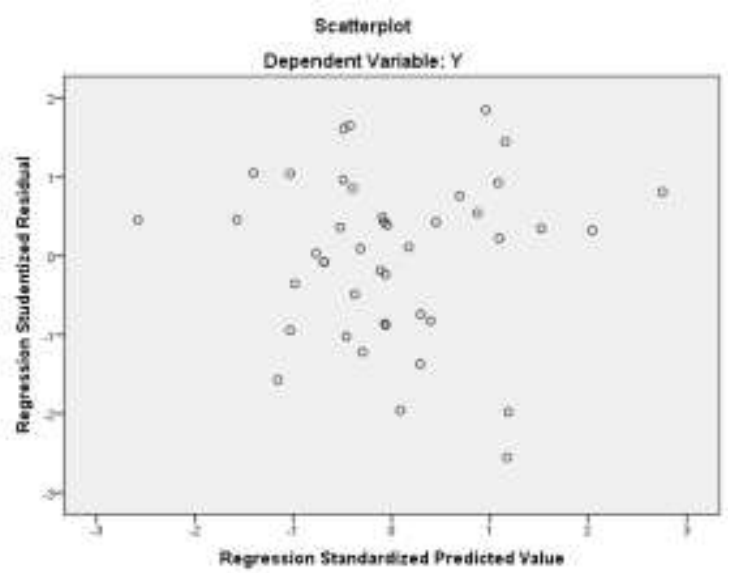

Sumber: Hasil output SPSS 20, 2019

Berdasarkan grafik scatter plot dari atas dapat lihiat bahwa titik menyebar secara merata di atas angka nol sehinga hasil pengamatan disimpulkan tidak terjadi masalah heteroskedastisitas. c. Uji Autokorelasi

Tabel 4.14

Uji Dubrin-Watson

\begin{tabular}{|c|c|c|c|c|c|}
\hline Model & $\mathrm{R}$ & R Square & $\begin{array}{c}\text { Adjusted R } \\
\text { Square }\end{array}$ & $\begin{array}{c}\text { Std. Error of } \\
\text { the Estimate }\end{array}$ & $\begin{array}{c}\text { Durbin- } \\
\text { Watson }\end{array}$ \\
\hline 1 &, $799^{\mathrm{a}}$ &, 639 &, 590 & 1,59561 & 1,993 \\
\hline
\end{tabular}

b. Dependent Variable: $Y$

Sumber: Hasil output SPSS 20, 2019

Hasil pengujian yang dilakukan diketahui nilai DW sebesar 1,993 dan melihat dari tabel Durbin-Watson nilai DU sebesar 1,7794 maka nilai DW 1,993 > nilai DU 1,7794. Maka dapat disimpulkan bahwa tidak terdapat autokorelasi.

d. Uji Multikolineartitas

Tabel 4.15

Uji VIF

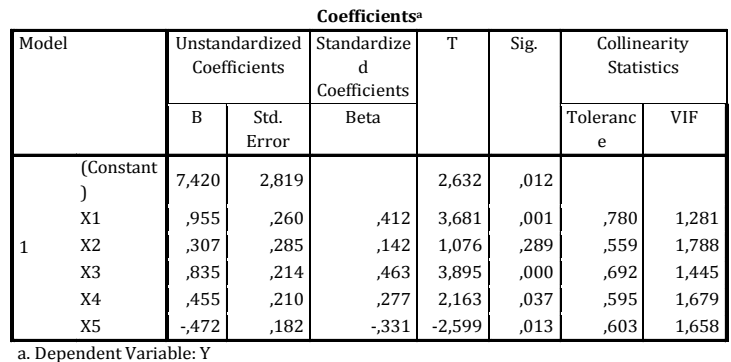

Sumber: Hasil output SPSS 20, 2019

Hasil pengujian Multikolineartitas melihat dari tabel VIF bahwa nilai tolerance pada program pelatihan dan pendidikan sebesar 0,780, keterlibatan pemakai sebesar 0,559, kemampuan teknik personal sebesar 0,692, fasilitas sebesar 0,595 dan dukungan manajemen puncang sebesar 0,603 yang berarti semua nilai tolerance pada variabel $\mathrm{X}$ $>0,10$. Dan melihat dari nilai VIF, semua variabel X menunjukkan nilai $\mathrm{VIF}<10,00$. Maka dapat disimpulkan bahwa hasil penelitian ini tidak terjadi multikolinearitas. 
e. Uji Regresi Linear Berganda

\begin{tabular}{|c|c|c|c|c|c|c|}
\hline \multicolumn{7}{|c|}{ Coefficients ${ }^{\mathrm{a}}$} \\
\hline \multirow{2}{*}{\multicolumn{2}{|c|}{ Model }} & \multicolumn{2}{|c|}{$\begin{array}{l}\text { Unstandardized } \\
\text { Coefficients }\end{array}$} & \multirow{2}{*}{$\begin{array}{c}\begin{array}{c}\text { Standardiz } \\
\text { ed } \\
\text { Coefficients }\end{array} \\
\text { Beta }\end{array}$} & \multirow[t]{2}{*}{$\mathrm{T}$} & \multirow[t]{2}{*}{ Sig. } \\
\hline & & B & Std. Error & & & \\
\hline \multirow{6}{*}{1} & $\begin{array}{l}\text { (Constan } \\
\text { t) }\end{array}$ & 7,420 & 2,819 & & 2,632 & ,012 \\
\hline & $\mathrm{X} 1$ & 955 & 260 & 412 & 3,681 & 001 \\
\hline & $\mathrm{X} 2$ & 307 & 285 & 142 & 1,076 & 289 \\
\hline & X3 & 835 & 214 & 463 & 3,895 & 000 \\
\hline & $\mathrm{X} 4$ & 455 & 210 & 277 & 2,163 & ,037 \\
\hline & $\mathrm{X} 5$ & 472 & ,182 & ,331 & 2,599 & ,013 \\
\hline
\end{tabular}

f. Uji F

Tabel 4.16

\begin{tabular}{|c|c|c|c|c|c|c|}
\hline \multicolumn{7}{|c|}{$\begin{array}{l}\text { Uji F } \\
\text { ANOvA }^{a}\end{array}$} \\
\hline Mod & & $\begin{array}{c}\text { Sum of } \\
\text { Squares }\end{array}$ & & Mean Square & $\mathrm{F}$ & Sig. \\
\hline \multirow{3}{*}{1} & Regression & \begin{tabular}{r|}
166,543 \\
\end{tabular} & 5 & 33,309 & 13,083 &, $000^{4}$ \\
\hline & Residual & 94,201 & 37 & 2,546 & & \\
\hline & Total & 260,744 & 42 & & & \\
\hline
\end{tabular}

Sumber: Hasil output SPSS 20, 2019

Nilai $\mathrm{F}_{\text {tabel }}$ dapat dicari dengan rumus:

$F_{\text {tabel }}=F(k ; n-k)=F(5 ; 43-5)=(5 ; 38)=2,46$

Maka diketahui nilai $\mathrm{F}_{\text {tabel }}$ sebesar

2,46 dan nilai $F_{\text {hitung }}$ sebesar 13,083 dan nilai probabilitas 0,000 . Nilai $F_{\text {hitung }}>F_{\text {tabel }}$ dan nilai signifikansi lebih kecil dari 0.05 , maka Hipotesis diterima. Variabel bebas secara simultan berpengaruh signifikan terhadap variabel Y.

g. Uji t

Berdasarkan hasil uji regression, dengan meggunakan program SPSS 20, maka dipoleh tabel sebagai berikut:

\section{Tabel 4.17}

Uji t

Sumber: Hasil output SPSS 20, 2019

Dengan rumus Regresi sebagai berikut: $\gamma=7,420+0,955+0,307+0,835+0,455-0$,

$$
+\epsilon
$$

Jika $t_{\text {hitung }}>t_{\text {tabel }}$ maka $\mathrm{H}_{0}$ ditolak berarti $\mathrm{H}_{1}$ diterima.

$$
\begin{aligned}
& t_{\text {tabel }}=\mathrm{T}(\alpha / 2 ; \mathrm{r}-\mathrm{k}-1)=\mathrm{t}(0,05 / 2 ; 43-5- \\
& 1)=\mathrm{t}(0,025 ; 37)=2,0261
\end{aligned}
$$

1) Program Pelatihan dan Pendidikan
Pada tabel koefisien kolom model 1 terdapat nilai signifikansi 0,001 . Nilai signifikansi yang ditunjukan tersebut lebih besar dari nilai 0,05 , yang berarti $\mathrm{H}_{1}$ diterima. Nilai $\mathrm{t}$ sebesar 3,681 menunjukkan bahwa variabel $\mathrm{X}_{1}$ memiliki hubungan yang searah dengan $Y$. Program pelatihan dan pendidikan memiliki pengaruh signifikan terhadap kinerja sistem informasi akuntansi.

2) Keterlibatan pemakai

Pada tabel koefisien kolom model 1 dilihat bahwa nilai signifikansinya 0,289. Nilai signifikansi yang ditunjukan tersebut lebih besar dari nilai 0,05, yang berarti $\mathrm{H}_{2}$ ditolak. Nilai t sebesar 1,076 menunjukkan bahwa variabel $\mathrm{X}_{2}$ tidak memiliki hubungan yang searah dengan $Y$. Keterlibatan pemakai dalam pengembangan sistem tidak memiliki pengaruh signifikan terhadap kinerja sistem informasi akuntansi.

3) Kemampuan teknik personal

Pada tabel koefisien kolom model 1 dilihat bahwa nilai signifikansi sebesar 0,000 . Nilai signifikansi yang ditunjukan tersebut lebih kecil dari nilai 0,05 , yang berarti $\mathrm{H}_{3}$ diterima. Nilai t positif sebesar 3,895 menunjukkan bahwa variabel $\mathrm{X}_{3}$ memiliki hubungan yang searah dengan $Y$. Kemampuan teknik personal memiliki pengaruh signifikan terhadap kinerja sistem informasi akuntansi.

4) Fasilitas

Pada tabel koefisien kolom model 1 dilihat nilai signifikansi sebesar 0,037. Nilai signifikansi yang ditunjukan tefscebut lebih kecil dari nilai 0,05, yang berarti $\mathrm{H}_{4}$ diterima. Nilai $\mathrm{t}_{\text {hitung }}$ positif sebesar 2,163 dan nilai $t_{\text {tabel }} 2.0261$ sehingga $t_{\text {hitung }}<t_{\text {tabel}}$, maka $X_{4}$ memiliki hubungan yang searah dengan $Y$. Fasilitas memiliki pengaruh signifikan terhadap kinerja sistem informasi akuntansi.

5) Dukungan manajemen puncak 
Pada tabel koefisien kolom model 1 dilihat nilai signifikansi sebesar 0,013. Nilai signifikansi yang ditunjukan tersebut lebih kecil dari nilai 0,05 , yang berarti $\mathrm{H}_{5}$ diterima. Nilai $t_{\text {hitung }}$ sebesar 2,599 dan nilai $t_{\text {tabel }} 2,0261$ sehingga $t_{\text {hitung }}$ $<t_{\text {tabel}}$, maka $\mathrm{X}_{4}$ memiliki hubungan yang searah dengan Y. Dukungan manajemen puncak memiliki pengaruh signifikan terhadap kinerja sistem informasi akuntansi.

h. Uji Determinasi

Tabel 4.18

Adjusted R Square

Model Summary

\begin{tabular}{|c|c|c|c|c|}
\hline Model & $\mathrm{R}$ & R Square & $\begin{array}{l}\text { Adjusted R } \\
\text { Square }\end{array}$ & $\begin{array}{l}\text { Std. Error of } \\
\text { the Estimate }\end{array}$ \\
\hline 1 & ,799a & 639 & ,590 & 1,59561 \\
\hline
\end{tabular}

Sumber: Hasil output SPSS 20, 2019

Hasil Pengujian berdasarkan tabel model summary, diketahui $\mathrm{R}$ Square sebesar 0,639. Nilai $\mathrm{R}$ Squre yang didapatkan dikali $100 \%$ menjadi $63,9 \%$. Ini mengartikan bahwa pada variabel $\mathrm{X}$ (program pelatihan dan pendidikan, keterlibatan pemakai, kemampuan teknik personal, fasilitas, dan dukungan manajemen puncak) memiliki nilai sebesar $63,9 \%$ sedangkan sisanya $36,1 \%$ dipengaruhi oleh faktor lain yang tidak diteliti dalam penelitian ini.

\section{Pengaruh Program Pendidikan dan Pelatihan terhadap Kinerja Sistem Informasi Akuntansi}

Hasil pengujian yang dilakukan bahwa hipotesis pertama diterima, dengan menujukkan nilai signifikannya sebesar $0,001<0,05$. Hasil penelitian ini konsisten dengan penelitian yang dilakukan oleh Chosamasatu (2014), Pemaghis(2015), Immelda (2015), Susilatri (2010) dan Prabowo (2013) bahwa program pelatihan dan pendidikan berpengaruh positif terhadap kinerja sistem informasi akuntansi.

Program pelatihan dan pendidikan yang dilaksanan PT. Sinar Galesong Mandiri terhadap karyawannya agar dapat menambah pengetahuan karyawan sehingga dalam pelaksanaan tugas dapat meningkatkan kinerja sistem informasi akuntansi diperusahaan tersebut

\section{Pengaruh Keterlibatan Pemakai terhadap Kinerja Sistem Informasi Akuntansi.}

Hasil pengujian yang dilakukan bahwa hipotesis kedua $\left(\mathrm{H}_{2}\right)$ ditolak ditunjukkan dengan nilai signifikannya sebesar 0,289>0,05. Penelitian yang dilakukan pemaghis (2015) konsisten dengan hasil penelitian ini bahwa variabel keterlibatan pemakai tidak berpengaruh signifikan terhadap kinerja sistem informasi akuntansi.

Melihat data kuesioner responden bahwa tingkat partisipasi dan pengaruh cukup dalam pengembangan sistem informasi akuntansi. Menurut responden bahwa yang terdapat dalam sistem, telah membantu pekerjaan.

\section{Pengaruh Kemampuan Teknik Personal terhadap Kinerja Sistem Informasi akuntansi}

Hasil penelitian ini bahwa hipotesis ketiga diterima $\left(\mathrm{H}_{3}\right)$ ditunjukkan dengan nilai signifikannya sebesar $0,000<0,05$. Hasil penelitian ini konsisten dengan penelitian yang dilakukan Nurhelmiah (2014), Pemaghis (2015), Saebani dan Anita (2016), Ramdhan (2016) bahwa kemampuan teknik personal memiliki pengaruh terhadap kinerja sistem informasi akuntansi. Kemampuan yang dimiliki karyawan akan memudahkan dan tidak menghambat pekerjaan sehingga pekerjaan dapat terselesaikan tepat pada waktunya. 


\section{Pengaruh Fasilitas terhadap Kinerja Sistem Informasi Akuntansi}

Hasil penelitian ini bahwa hipotesis keempat diterima $\left(\mathrm{H}_{4}\right)$. Ditunjukkan dengan nilai signifikannya sebesar $0,037<0,05$. Hasil penelitian ini konsisten dengan yang dilakukan Rukmawati dan I Ketut (2016) bahwa variabel ini memiliki pengaruh terhadap kinerja sistem informasi akuntansi. Fasilitas yang dimaksud perangkat lunak(software) dan perangkat keras (hardware) sehingga memudahkan proses input dan output data dalam pembuatan informasi. Selain itu, sistem informasi akuntansi yang tersedia memiliki penampilan fisik yang sesuai dengan pelayanan yang diberikan sehingga memudahkan responden dalam pengenalan sistem dan juga sistem informasi akuntansi tersebut dapat diandalkan oleh penggunanya.

\section{Pengaruh Dukungan Manajemen Puncak terhadap Kinerja Sistem Informasi Akuntansi}

Hasil penelitian ini bahwa hipotesis kelima diterima $\left(\mathrm{H}_{5}\right)$. Ditunjukkan dengan nilai signifikannya sebesar 0,013>0,05. Hasil penelitian ini konsisten dengan penelitian yang dilakukan oleh Chosamasatu (2014), Pemaghis (2015) dan Immelda (2015) bahwa dukungan manajemen puncak memiliki pengaruh terhadap kinerja sistem informasi akuntansi. Melihat dari data responden bahwa manajemen puncak mendukung karyawan dengan penyediaan sistem infromasi akuntansi seperti software dan hardare dalam pembuatan data informasi akuntansi perusahaan. Pimpinan manajemen puncak juga terlibat secara aktif dalam perencanaan operasi dan pengembangan sistem informasi akuntansi dan melakukan evaluasi atas hasil outputI dari kinerja sistem infromasi akuntansi.

\section{PENUTUP}

\section{a. Simpulan}

1. Program pelatihan dan pendidikan berpengaruh secara signifikan terhadap kinerja sistem informasi akuntansi ditunjukkan dengan nilai $0,001<0,05$

2. Keterlibatan pemakai berpengaruh tidak signifikan terhadap kinerja sistem informasi akuntansi ditunjukkan dengan nilai 0,289>0,05.

3. Kemampuan Teknik Personal berpengaruh secara signifikan terhadap kinerja sistem informasi akuntansi ditunjukkan dengan nilai $0,000<0,05$.

4. Fasilitas berpengaruh secara signifikan terhadap kinerja sistem informasi akuntansi ditunjukkan dengan nilai $0,037<0,05$.

5. Dukungan Manajemen Puncak berpengaruh secara signifikan terhadap kinerja sistem informasi akuntansi ditunjukkan dengan nilai $0,013>0,05$.

\section{b. Saran}

1. Bagi peneliti selanjutnya, agar menambah beberapa varibel lain yang menjelaskan $36,1 \%$ yang tidak dapat dijelaskan dalam penelitian ini. Untuk memperluas lingkup wilayah penelitian dibeberapa perusahaan untuk dapat menambah responden. Selain itu diharapkan dapat menggunakan metode pengumpulan data wawancara untuk mendapatkan informasi yang lebih akurat dan juga responden dapat memahami pernyataan yang diajukan/diberikan.

2. Bagi perusahaan agar melibatkan pemakai sistem dalam proses pengembangan sistem karena mereka adalah pihak yang berhubungan 
langsung dalam pengoperasian sistem informasi yang digunakan.

\section{DAFTAR PUSTAKA}

Aprianto, B dan Fonny, A. 2013. Pedoman Lengkap Profesional SDM Indonesia. PPM: Jakarta Pusat.

Biwi, dkk. 2015. Pengaruh Kapabilitas Personal Dan Dukungan Manajemen Puncak Terhadap Kinerja Sistem Informasi Akuntansi PT. Tirta Mumbul Jaya Abadi Singaraja. EJournal S1 AK. Volume 3 No.1.

Chosamasatu, Yuli. 2014. Faktor-Faktor yang Mempengaruhi 'Performance of Accounting Information System'. Jurnal Paradigma. Volume 12 No.1.

Darmawan. 2013. Metode Penelitian Kuantitatif. Remaja Rosdakarya: Bandung.

Diana dan Setiawati. 2011. Sistem Informasi Akuntansi, Perancangan, Proses dan Penerapan. Andi Yogyakarta. Yogyakarta.

Fani, dkk. 2015. Pengaruh Kecanggihan Teknologi Informasi, Kemampuan Teknik Pemakai, Dan Dukungan Manajemen Puncak Terhadap Kinerja Sistem Informasi Akuntansi Studi Empiris Pada PT PLN (Persero) Area Bali Utara (Kantor Pusat). Ejournal S1 AK. Volume 3 No.1.

Fitri, N. 2012. Faktor-Faktor yang Memengaruhi Kinerja Pemakai Sistem Informasi Akuntansi Pada Perusahaan Farmasi Di Medan. Tesis dipublikasikan. Medan: Pascasarjana Universitas Sumatera Utara.

Ghozali, Imam. 2009. Analisis Multivariate dengan Program SPSS. Edisi 4. Badan Penerbit Universitas Diponegoro. Semarang

Hall, James A. (2009). Accounting Informastion System. Salemba Empat: Jakarta.
Immelda, S. C. 2015. Analisis FaktorFaktor Yang Mempengaruhi Kinerja Sistem Informasi Akuntansi Pada Pt. DBTR Sidoarjo. Skripsi. Kediri. Universitas Nusantara PGRI Kediri.

Indriantoro, Nur dan Supomo. 2014. Metodologi Penelitian Bisnis untuk Akuntansi dan Manajemen. BPFE: Yogyakarta

Kharisma dan Gede. 2017. Pengaruh Keterlibatan Pemakai, Kemampuan Pemakai, Pelatihan Dan Pendidikan Pemakai Terhadap Kinerja Sistem Informasi Akuntansi. Jurnal Akujiuntansi. Volume 19 No.3.

Krismaji. 2010. Sistem Informasi Akuntansi. UPP AMP YKPN: Yogyakarta.

La, Ane dan Putri Nanda Anggraini. 2012. Faktor-Faktor yang Mempengaruhi Kinerja Sistem Informasi Akuntansi Di Lingkungan Pemerintahan Daerah Serdang Bedagai. Jurnal Telaah Akuntansi. Volume 14 No.2.

Mardi. 2016. Sistem Informasi Akuntansi. Ghalia Indonesia: Bogor

Marlinah, Andi. 2010. Pengaruh Kinerja Sistem Terhadap Kepuasan Pengguna Pada PT.Bank Muamalat Indonesia. $\quad$ http://e-journalindonesia.ac.id/. Diakses pada tanggal 23 Maret 2019.

Maryana, dkk. 2018. Pengaruh Kualitas Sistem Dan Kualitas Informasi Terhadap Kepuasan Pengguna Aplikasi Pelayanan Pelanggan Terpusat (Ap2t) Pt Pln (Persero) Wilayah Kalimantan Tengah Dan Kalimantan Selatan Area Barabai. Jurnal Ekonomi dan Bisnis Volume11 No.2.

Mulyadi. 2010. Sistem Akuntansi. Salemba Empat: Jakarta.

Nisfiannoor, M. 2009. Pendekatan Statistika Modern untuk Ilmu Sosial. Jakarta: Salemba Humanika. 
Nurhelmiah. 2014. Faktor-Faktor yang Memengaruhi Kinerja Pemakai Sistem Informasi Akuntansi. Skripsi. Makassar. Universitas Hasanuddin.

Pemaghis, Cristalia Wirakartika Putri. 2015. Faktor-Faktor yang Mempengaruhi Kinerja Sistem Informasi Akuntansi (Sia) Pada Bank Perkreditan Rakyat (Bpr) Eks. Karesidenan Surakarta. Skripsi. Surakarta. Universitas Muhammadiyah Suakarta.

Prabowo, dkk. 2013. Faktor-Faktor yang Memengaruhi Kinerja Sistem Informasi Akuntansi Di Bank Umum Kota Surakarta. Jupe UNS. Volume 2 No.1.

Prasetyo, H., dan Sutopo, W. 2017. Industri 4.0: Telaah Klasifikasi Aspek dan Arah Perkembangan Riset. Jurnal Teknik Industri. Volume 3 No.1.

Putra, Y.R.K. 2014. Analisis Faktor-Faltor Yang Mempengaruhi Kinerja Sistem Informasi Akuntansi Pada Dinas Kesehatan Provinsi Jawa Timur. Skripsi. Universitas Pembangunan Nasional Veteran. Jawa Timur.

Ramadhan, dkk. 2016. Faktor-Faktor yang Mempengaruhi Kinerja Pemakai Sistem Informasi Akuntansi Pada Pt. Kubota Indonesia Wilayah Semarang. Journal of Accounting. Volume 2 No.2.

Rivanigrum, Ajeng. 2015. Faktor-Faktor Yang Mempengaruhi Kinerja Sistem Informasi Akuntansi Pada Rumah Sakit Saras Husada Purworejo. Skripsi. Universitas Negeri Semarang.

Rukmiyati dan I ketut. Pengaruh Kualitas Sistem Informasi, Kualitas Informasi Dan Perceived Usefulness Pada Kepuasan Pengguna Akhir Software Akuntansi (Studi Empiris Pada Hotel Berbintang Di Provinsi Bali. Jurnal Ekonomi dan Bisnis (2016): 115142. ISSN 2337-3067
Saebani dan Anita. 2016. Analisis FaktorFaktor yang Memengaruhi Kinerja Sistem Informasi Akuntansi. Jurnal Sosial, Ekonomi, dan Humaniora. Volume 6 No.1.

Salmah, Ninin Non Ayu. 2012. Pengaruh Program Pelatihan Dan Pengembangan Karyawan Terhadap Kompetensi Karyawan Pada PT. Muba Electric Power Sekayu. Jurnal Ekonomi dan Informasi Akuntansi. Volume 2 No.3.

Setyadharma, Andryan. 2010. Asumsi Klasik dengan SPSS 16. Badan Penerbit Univesitas Negeri Semarang. Semarang

Sugiyono. 2013. Metode Penelitian Kuantitatif Kualitatif dan $R D$. Alfabeta: Bandung.

Suharni, Sitti. 2016. Pengaruh Keterlibatan Pemakai dan Kemampuan Pemakai Terhadap Kinerjas Sistem Informasi Akuntansi Pada Sekretariat Daerah Dan BKD Kabupaten Ngawi. Jurnal Sosial. Volume 12 Nomor 2.

Susilatri, Amris Rusli Tanjung, dan Surya Pebrina. 2010. Faktor-Faktor yang Mempengaruhi Kinerja Sistem Informasi Akuntansi Pada Bank Umum Pemerintah Dikota Pekanbaru. Jurnal Ekonomi. Volume 18 No.2.

Wikipedia. 2019. Kinerja. https://id/m/org.wiki/Kinerja. Diakses pada tanggal 10 Maret. 2019. 